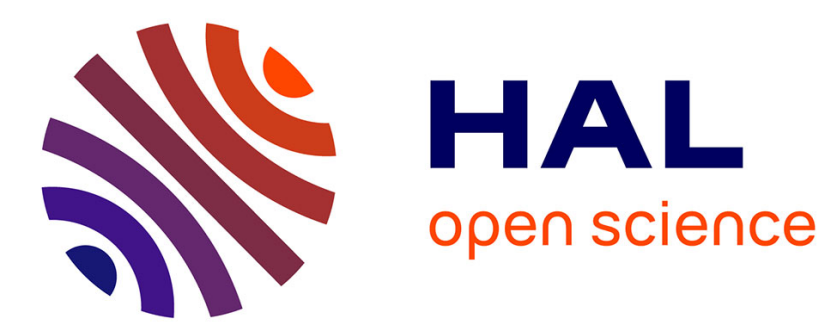

\title{
First Occurrence of the Genus Australatya (Crustacea: Decapoda: Atyidae) in Melanesia and Polynesia with Description of a New Species
}

\author{
Camille Lorang, Gérard Marquet, Valentin de Mazancourt
}

\section{- To cite this version:}

Camille Lorang, Gérard Marquet, Valentin de Mazancourt. First Occurrence of the Genus Australatya (Crustacea: Decapoda: Atyidae) in Melanesia and Polynesia with Description of a New Species. Pacific Science, 2020, 74 (3), pp.297-308. 10.2984/74.3.7 . hal-03303256

\section{HAL Id: hal-03303256 https://hal.science/hal-03303256}

Submitted on 28 Jul 2021

HAL is a multi-disciplinary open access archive for the deposit and dissemination of scientific research documents, whether they are published or not. The documents may come from teaching and research institutions in France or abroad, or from public or private research centers.
L'archive ouverte pluridisciplinaire $\mathbf{H A L}$, est destinée au dépôt et à la diffusion de documents scientifiques de niveau recherche, publiés ou non, émanant des établissements d'enseignement et de recherche français ou étrangers, des laboratoires publics ou privés. 
3 First occurrence of the genus Australatya (Crustacea: Decapoda: Atyidae) in Melanesia 4 and Polynesia with description of a new species.

6 Camille Lorang ${ }^{1}$, Gérard Marquet $^{1}$ and Valentin de Mazancourt ${ }^{1,2}$ *

7

$8{ }^{1}$ Muséum national d'Histoire naturelle, Unité Biologie des organismes et écosystèmes 9 aquatiques (BOREA), MNHN, Sorbonne Université, UCN, UA, CNRS, IRD, CP26, 57 rue 10 Cuvier 75005 Paris, France.

112 Museum für Naturkunde, Leibniz Institute for Evolution and Biodiversity Science, 12 Invalidenstraße 43, 10115 Berlin, Germany.

Introduction

* Corresponding author. E-mail: valentin.demazancourt@laposte.net

Abstract: During specific inventories led by the Muséum national d'Histoire naturelle (MNHN, Paris), numerous specimens of Atyidae, particularly of Atya-like shrimps were collected in Melanesia (Vanuatu, Solomon Islands) and in Polynesia (Futuna, Samoa). These specimens were morphologically and genetically examined. Our study revealed that some specimens belonged to a new species in the genus Australatya Chace, 1983. The aim of this paper is to describe this new species, Australatya keithi sp. nov., and discuss the distribution of its genus in the studied area. 
Until recently, the taxonomy of Atyidae was mainly based on morphological characters. But, in the Caridina genus, some characters have been proven highly variable within a species (e.g. rostrum shape and indentation or coloration) and therefore taxonomically uninformative, making it difficult to establish boundaries between them (von Rintelen and Cai 2009, de Mazancourt et al. 2017). Thus, there is a need for an integrative and standardized approach to improve the group's systematics, focusing on informative morphological features and using molecular characters (Page et al. 2005, Page and Hughes 2011). To illustrate this problem, we focus here on the genus Australatya Chace, 1983. It has a wide but disjoint distribution in the Indo-Pacific region and includes until now only three species: Australatya striolata (McCulloch and McNeill 1923) and Australatya hawkei Choy, Page and Mos, 2019 from Australia and Australatya obscura Han and Klotz, 2015 from the Philippines, Taiwan (Han and Klotz 2015) and Ryukyu islands (Inui et al. 2019). This genus occurs in the higher course of tropical rivers like other Atya-like shrimps (Atyoida pilipes (Newport, 1847) or Atyopsis spinipes (Newport, 1847)). Only a few studies provided DNA data for species of Australatya (see Cook et al. 2012; Han and Klotz, 2015; Choy et al. 2019).

One of the aims of the Muséum national d'Histoire naturelle (MNHN, Paris) is to carry out faunistic inventories of rivers in tropical islands in order to establish better protection of these fragile ecosystems and, in this context, to clarify the taxonomy of poorly known organisms. For our study, several Pacific islands were surveyed: Futuna (Territory of Wallis and Futuna) in October 2004 (Mary et al. 2006), Upolu (Samoa) in July 2008 (Keith et al. 2013) and again in August 2014. Kolombangara and Vella Lavella islands (Solomon Islands) respectively in November 2015 and October 2016, and Santo and Aneityum (Vanuatu) respectively in July 2005 and June 2015. As we collected specimens from these different islands from the Pacific Ocean, we started to question the identity of some specimens previously identified as Atyoida pilipes or Atyopsis spinipes collected from these islands. The aim of this study is thus to 
combine morphological data with a $16 \mathrm{~S}$ rDNA analysis to investigate the "Atya-like" shrimps present in the sampled area.

\section{Collection of specimens}

Specimens from Pacific islands were collected by electrofishing (portable Dekka 3,000 electric device, or SAMUS 1,000: http://www.electro-fisher.net/). All material was preserved in $75 \%-95 \%$ alcohol and has been deposited in the collections of the MNHN in Paris.

\section{Morphological comparison}

The rostrum, the general cephalon, the pereopods 1, 2, 3 and 5 and the abdomen were observed using a stereoscopic microscope. The proportions of the various joints of the appendages were measured using microphotographs and AnalySIS Works software (Olympus). Drawings were made using the 'Digital Inking' method (Coleman 2003, 2006) by tracing vectorial paths on stacks of high-resolution photographs using Adobe Illustrator (CS6).

\section{Abbreviations for morphological analyses}

The following abbreviations are used in the present text: cl, carapace length (mm): measured from the post-orbital margin to the posterior margin of the carapace. P1: first pereopod. P2: second pereopod. P3: third pereopod. P5: fifth pereopod. P11: first male pleopod. P12: second male pleopod. 
Molecular analyses were conducted on mitochondrial DNA, on the $16 \mathrm{~S}$ ribosomal RNA fragment, in order to differentiate each specimen by species and location. A total of 10 specimens of Australatya were genetically studied.

Total DNA was extracted from abdominal muscle samples using the NucleoSpin 96 Tissue Core (Macherey-Nagel) protocol. For each sample, PCR reactions contained: $15.44 \mu 1$ of $\mathrm{H}_{2} \mathrm{O}, 2 \mu \mathrm{l}$ of Taq buffer $\left(15 \mathrm{mM}+\mathrm{MgCl}_{2}\right), 1 \mu 1$ of DMSO $(1 \mathrm{ng} / \mathrm{ml}), 1 \mu 1$ of BSA, $0.8 \mu 1$ of dNTP $\quad(6.6 \quad \mathrm{mM}), \quad 0.32 \mu \mathrm{l}$ of Forward primer (16Sar-Lmod: TACTTCTGCCTGTTTATCAAAAA) and $0.32 \mu \mathrm{l}$ of Reverse primer (16Sbmod: GGTCTGAACTCAAATCATGTAAA), both at $10 \mathrm{pM}, 0.12 \mu \mathrm{l}$ of Taq polymerase (Qiagen), and $3 \mu 1$ of purified DNA from extraction. PCR program was: 4 min at $94^{\circ} \mathrm{C}$, then 35 cycles in three steps with $30 \mathrm{sec}$ at $94^{\circ} \mathrm{C}, 40 \mathrm{sec}$ at $42^{\circ} \mathrm{C}$ and $1 \mathrm{~min}$ at $72^{\circ} \mathrm{C}$. The program finished with $7 \mathrm{~min}$ at $72^{\circ} \mathrm{C}$. PCR products were sequenced using Sanger method in both directions to minimize mistakes.

\section{Molecular analysis}

Analyses were performed using Geneious 7.1.8. A multiple alignment was realized between all sequences with the MUSCLE algorithm (Edgar 2004). Using Bayesian information criterion in jModelTest (Guindon and Gascuel 2003, Darriba et al. 2012) we retained the GTR $+\mathrm{G}+\mathrm{I}$ model. From this alignment, a phylogenetic tree was produced by MrBayes 3.2.6, available on CIPRES Science Gateway V3.3 server (Miller et al. 2010, https://www.phylo.org), running for 10,000,000 generations, a sampling frequency of 1,000 and a burn in of $10 \%$. Support for nodes was determined using posterior probabilities calculated by MrBayes. With MEGA X (Kumar et al. 2018), another phylogenetic tree was made by maximum likelihood using the same substitution model. Robustness of the nodes 
101 replicates.

102 Species delimitation analyses were realized with the ABGD v. 07/12/18 method (Puillandre et

103 al. 2011) to estimate intra and interspecific divergence in our data using JC69 distances.

104 Priors were left as default (Pmin: 0.001; Pmax 0.1; 10 steps; relative gap width: 1.5; 20 bins).

Results and Discussion

\section{Morphological analyses}

109 Measures and observations made on the specimens caught allowed us to separate them into

110 three genera, i.e. Atyoida, Atyopsis and Australatya. The general criteria to identify species of

111 the genus Atyoida are P1 and P2 with chelae heteromorphic (with or without palm), P3

112 without meral spur in large males, 3rd maxilliped with uncinate terminal spine, P11 of male

113 with endopod tapering sinuously but rather regularly to slender apex, for genus Atyopsis are

114 P1 and P2 with chelae monomorphic (without palm), P3 with prominent spur on merus in

115 large males, 3rd maxilliped not terminating in single apical spine, P11 of male with endopod

116 rigid, rhomboidally oval, submarginally spinose, for Australatya are P1 and P2 with chelae

117 monomorphic (without palm), P3 without meral spur in large males, interno-inferior margin

118 of merus forming a carina with 4-9 strong teeth-like spiniform setae, third maxilliped

119 dimorphic between sexes, with uncinate terminal spiniform seta (nail) partially concealed by

120 dense serrate setae in males, tip rounded, without a nail in females, P11 of male with endopod

121 tapering to slender apex. The species found in this last genus is new. The description of this

122 species follows thereafter. 11 specimens of Australatya have been identified in our samples: 3

123 from the Solomon Islands, 2 from Futuna, 4 from Samoa and 2 from Vanuatu. 
126 A total of 34 sequences of $16 \mathrm{~S}$ were used in the analysis, including 10 sequences of 127 Australatya newly produced and 3 retrieved from GenBank. As outgroups, 8 sequences of 128 Atyopsis, 12 of Atyoida and one of Atya gabonensis were retrieved from GenBank (Table 1).

129 As the two phylogenetic trees obtained by Maximum Likelihood (ML) and Bayesian

130 Inference (BI) were congruent, only the Bayesian tree is shown here. Support values above

131 branches are BI posterior probabilities and below branches are ML bootstrap numbers (Fig.

132 1). These trees confirm the presence of the Australatya genus in our samples. Most of the 133 nodes are highly supported ( $\mathrm{PP}>0.98$ and $\mathrm{B}>95)$ in both ML and BI methods. The ABGD 134 method found 8 species in our sampling: Atya gabonensis, Atyoida bisulcata, Atyoida pilipes, 135 Atyopsis spinipes, Atyopsis moluccensis, Australatya obscura, Australatya striolata and the 136 new species we caught, Australatya keithi sp. nov.. This indicates that the latter is genetically 137 distinct from the other species. The names of the taxa in the tree (Fig. 1) appear in accordance 138 with the ABGD results, except for Australatya striolata and Australatya hawkei which are 139 clustered together in a single species in the analysis. All the specimens identified as the new 140 species described in the present study cluster in a same highly supported clade $(\mathrm{PP}=1 ; \mathrm{B}=$ 141 100). There seems to be some population structure within that species, with two clusters being 142 distinctly separated from the specimens from Futuna and Samoa, one with specimens 143 collected from Vanuatu and the other with specimens from the Solomon Islands.

144
$<$ Table 1 here $>$

$<$ Figure 1 here $>$ 
Family Atyidae De Haan, 1849

Genus Australatya Chace, 1983

Australatya keithi sp. nov.

(Figure 2)

$<$ Figure 2 here $>$

Material examined:

Holotype. VANUATU. ANEITYUm: Inwe Lengei River, 1ð̋, cl 5.5 mm (MNHN-IU-2018-3302; DNA: CA1957), 20¹2.409'S, 16948.131'E, June 24, 2015, 200 m a.s.1., coll. D. Kalfatak, C. Lord, G. Segura. Paratypes. VANUAtu. Aneityum: 19 ovig., cl 6.8 mm (MNHN-IU-20183303; DNA: CA1958), same data as holotype. SOLOMON ISLANDS. KOLOMBANGARA. Vage River, 19 ovig., cl $4.0 \mathrm{~mm}$ (MNHN-IU-2018-3300; DNA: CA1934), $08^{\circ} 05.112^{\prime} \mathrm{S}$, 156 59.867'E, November 10, 2015, coll. P. Keith, G. Marquet, C. Lord. - vella Lavella. Maravari River, 19 ovig., cl 4.0 mm, (MNHN-IU-2018-3301; DNA: CA2359) 1 specimen (MNHN-IU-2018-3308; DNA: CA1944), 0751.703’S, 156²41.748’'E, October 10, 2016, coll. P. Keith and C. Lord. SAMOA. SAVAI. Ma'epu stream, $1 \sigma^{\widehat{y}}$ juvenile, cl $3.2 \mathrm{~mm}$ (MNHN-IU2018-3307), $13^{\circ} 51.919^{\prime} S, 171^{\circ} 41.174^{\prime} \mathrm{W}$, July 07, 2014, 20-50 m a.s.1., coll. P. Gerbeaux. UPolu. Tuafaleloa River, 19 ovig., cl 5.3 mm (MNHN-IU-2018-3304; DNA: CA1947) and 19 ovig., cl 5.7 mm (MNHN-IU-2018-3305; DNA: CA1948), 1353.644'S, 171 ${ }^{\circ} 30.922^{\prime} \mathrm{W}$, July 08, 2014, 100 m a.s.1., coll. P. Gerbeaux. Faleata River, 1 + ovig., cl 5.0 mm (MNHN-IU2018-3306; DNA: CA2422), 1343.741'S, $172^{\circ} 18.832^{\prime}$ W, July 12, 2014, 195 m a.s.1., coll. P. Gerbeaux. WALLIS AND FUTUNA. FUTUNA. Vainifao River, 19 , cl 6.1 mm (MNHN-Na-15761;

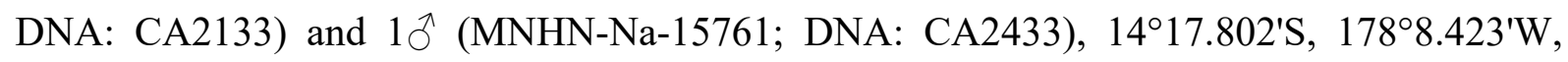
October 12, 2004, 151 m a.s.1., coll. P. Keith, G. Marquet, N. Mary. 
176 Comparative material:

177 Australatya hawkei Choy, Page \& Mos, 2019

178 AUSTRALIA. MNHN-Na-14383. Freshwater creek in Big Table Land, 1 q ovig., cl 10.0 mm,

179 North-East Queensland, November 18, 1993, coll. K. McDonald.

180

181 Description

182 Cephalothorax (Fig. 2m): Carapace length 4.0-6.1 $\mathrm{mm}(\mathrm{N}=7)$. Carapace smooth, inferior

183 orbital angle fused with a distinct antennal tooth; pterygostomian margin rectangular rounded.

184 Rostrum short, $0.2-0.3$ of $\mathrm{cl}$, reaching near to end of basal segment of antennular peduncle,

185 with feebly marked lateral carina, dorsal ridge unarmed. The number of ventral teeth on the

186 rostrum varies from 0 to 4 . Rostrum formula 0/0-4. Eyes well developed. Antennular

187 peduncle stout, $0.56(+)-0.46(\precsim)$ times as long as carapace; basal segment shorter than half

188 length of antennular peduncle, second segment longer than third segment. Stylocerite

189 reaching 0.86 length of the basal segment of antennular peduncle.

190 Pereiopods: P1 and P2 similar in size and shape. P1 chela (Fig. 2a) atyoid in shape, without

191 palm, 4.5-5.3 times as long as wide, without hooks; dactylus 4.9-5.8 times as long as wide,

192 with tufts of long setae distally; carpus short, cup-like 1.3-1.8 times as long as wide. P2 chela

193 (Fig. 2b) atyoid in shape without palm, 4.4-5.3 times as long as wide, tips of fingers rounded,

194 without hooks, dactylus 5.1-6.0 times as long as wide, with tufts of long setae distally; carpus

195 short, cup-like 1.2-1.7 times as long as wide. P3 (Fig. 2c) moderately strong, with a row of

196 small plumose setae on lateral margin from ischium to propodus; dactylus (Fig. 2e) 1.4-2.71

197 times as long as wide (terminal spiniform seta included), terminating in one large claw with

198 5-6 accessory spiniform setae on flexor margin, first spiniform setae distinctly smaller than

199 second; propodus with numerous small spiniform setae on ventral margin, distal pair of 
spiniform setae not much prolonged, propodus 3.3-4.4 times as long as wide, 2.4-6.1 times as

201 long as dactylus; merus with an interno-inferior margin forming a very distinctive carina with 5-7 strong, teeth-like spiniform setae. P5 (Fig. 2d) slender, dactylus (Fig. 2f), 1.6-3.5 times as long as wide (terminal spiniform seta included), terminating in one large claw, with 23-32 spiniform setae on flexor margin extending lateral to distal claw; propodus 6.3-8.6 times as long as wide, 3.6-6.8 times as long as dactylus.

206 Abdomen: Sixth abdominal somite 0.43 length of carapace, 1.25 times as long as fifth somite, 0.87 times as long as telson. Telson (Fig. 2j): slightly tapering distally, 2.4-3.5 times as long as proximally wide, distal 209 margin broadly rounded with a median projection, lateral angles not overreaching distal 210 margin, dorsal with 4-5 pairs of short spiniform setae and one pair of short spiniform setae 211 dorsolateral; distal margin with 2 strong spiniform setae lateral, in between 6-10 long, 212 plumose setae overreaching lateral spiniform setae.

213 P11 (Fig. 2k): Endopod of male subtriangular, 2.3 times as long as wide, reaching 0.29-0.41 214 times of exopod, with an appendix on the subdistal outer margin which reaches beyond distal 215 end of endopod with most of its length.

216 P12 (Fig. 21): Appendix masculina on second pleopod reaching 0.54-0.56 times length of 217 endopod; appendix interna reaching 0.77 of appendix masculina.

218 Triangular preanal carina (Fig. 2i) with a spine.

219 Uropodal diaeresis (Fig. 2h) with 15-21 spinules.

220 Eggs (Fig. 2g): developed (visible eyes) $0.32-0.45 \times 0.52-0.71 \mathrm{~mm}$, undeveloped $0.33-0.34 \times$ $221 \quad 0.51-0.57 \mathrm{~mm}$. 
224 This new species is named keithi in honor of Philippe Keith, professor at the MNHN, who 225 made extensive collections of both freshwater fish and crustaceans for more than 20 years in 226 the Pacific islands in particular in Kolombangara, Vella Lavella (Solomon Islands), in Santo 227 (Vanuatu archipelago) and Futuna island, where he collected,with one of us, the new 228 species here described,and photographed it (Figure 3) ; we appreciate his flawless friendship, 229 his constant enthusiasm in the field and his dedication to his team.

Habitat

233 This species, largely rheophile, was collected in the uppermost sections of streams (Fig. 3B).

234 It shared this habitat with other "Atya-like" shrimp (Atyoida pilipes, Atyopsis spinipes) and 235 with medium sized palaemonids like Macrobrachium latimanus (von Martens, 1868).

Color pattern

238 Body overall dark with white dorsal stripes on the abdomen (Fig. 3A).

$<$ Figure 3 here $>$

Distribution

243 This species occurs in Melanesia (Solomon Islands, Vanuatu) and in West Polynesia (Futuna 244 and Samoa) (Fig. 4). 
Genus Australatya Chace, 1983 now includes four species: Australatya keithi sp. nov., A. 250 striolata (MacCulloch and McNeill, 1923) and A. hawkei Choy, Page and Mos, 2019, both 251 from Australia, and A. obscura Han and Klotz, 2015 from Taiwan, the Philippines and 252 Ryukyu islands. Morphologically, specimens of the new species differ from A. striolata by 253 their rostrum armed with fewer ventral teeth 0-4 (vs 4-8 in A. striolata) and their shorter P3 254 propodus, 3.3-4.4 times as long as wide (vs 5.1-6.3). They differ from A. hawkei by their 255 rostrum armed with fewer ventral teeth $0-4$ (vs 5-8 in $A$. hawkei) and their shorter P3 256 propodus, 3.3-4.4 times as long as wide (vs 5.0-6.7). They differ from A. obscura by their 257 longer P1 carpus and P2 carpus 1.3-1.8 (vs 0.8-1.0 in A. obscura) and 1.2-1.7 (vs 0.9-1.0), 258 their P3 shorter propodus 3.3-4.4 times as long as wide (vs 5.3-6.9), and simple dactyli of the 259 fifth pereiopod (vs. biunguiculate).

Remarks.

262 According to Han and Klotz (2015), the row of prominent, teeth-like spiniform setae on the 263 interno-inferior margin of the merus of the third pereiopod, always present in adult specimens 264 of Australatya, with the sexual dimorphism of the distal segment of the third maxilliped 265 seems to be the best character to distinguish this genus from all other Atya-like genera of the 266 Indo-Pacific region. Our new species here described presents these same characteristics, thus 267 confirming its placement within Australatya.

268 Furthermore, Australatya keithi is differentiated from Atyopsis spinipes by its much smaller 269 body size; its merus of male specimens lacking a massive spur vs. having a massive spur in 270 large males; its endopod of males first pleopod tapering from proximal to distal vs. not 271 tapering from proximal to distal, rhomboidally oval, submarginally spinose; appendix masculina on second pleopod of males with spinose area distal to tip of appendix interna vs. 
273 spinose over more than half length; lateral angles of telson not overreaching distal margin vs.

274 overreaching.

275 The new species is distinguished from Atyoida pilipes by its chelae not sexually dimorphic vs.

276 dimorphic, with palm in male specimens, and its appendix masculina on second pleopod of

277 males with spinose area distal to tip of appendix interna vs. spinose area overlapping a part of 278 the appendix interna.

279

280 Identification key

281 1.1 Short P3 propodus 3.3-4.4 times as long as wide, A. keithi sp. nov.

282 (Solomon Islands, Vanuatu, Samoa, Futuna)

283 1.2 Long P3 propodus 5.0-6.9 times as long as wide .2

284

285

2.1 Short P1 carpus and P2 carpus 0.9-1.0 (Han and Klotz, 2015)

A. obscura

286 (Taiwan, Ryukyu, Philippines)

2.2 Long P1 carpus and P2 carpus 1.0-1.8 and 1.0-1.7 (Smith and Williams, 1982)....

3.1 Rostrum length/carapace length 0.32-0.45 (Smith and Williams, 1982)

A. striolata

290 (Australia: New South Wales, South Queensland)

3.2 Rostrum length/carapace length 0.21-0.31 (Choy et al. 2019) A. hawkei (Australia:

292 North Queensland)

293

Acknowledgements

296 For Futuna: We thank A. Malau, head of the Environment office of Wallis and Futuna, P.

297 Vanal and D. Labrousse. We also thank the King of the Sigave Kingdom, the King of the Alo 
Kingdom and the head of the rural economy office from Futuna. We acknowledge for their help on the field: Besamino, A. Dutartre, C. Flouhr, M. Juncker, N. Leleiva, N. Mary, P. Sasal and Soseto. For Solomon Islands: We thank Philippe Gerbeaux, Clara Lord and Robson Hevalo for their help collecting specimens in the field. Part of the study was made possible by a grant given to the French Ichtyological Society as part of the 'Critical Ecosystem 303 Partnership Fund (CEPF)' (Melanesia hotspot). The Critical Ecosystem Partnership Fund is a 304 joint initiative of l'Agence Française de Développement, Conservation International, the Global Environment Facility, the Government of Japan, the MacArthur Foundation and the World Bank. Part of the sampling was made possible by a grant of the Fondation de France for a freshwater fish biodiversity study. We acknowledge customary landowners and tribes

308 for allowing the expedition team to enter their customary lands. We also thank the Solomon

309 Islands Government for the support and facilitation of the legal process that have allowed the expedition team to conduct the scientific research in Solomon Islands and ESSI which

311 organised the trip very efficiently. For Samoa: We acknowledge the Samoan Ministry of

312 Natural Resources Environment and Meteorology, Conservation International, the Japan

313 International Cooperation Agency, the University of The South Pacific and the International

314 Union for Conservation of Nature. J. Atherton (CI) and N. Doherty (MNRE) played a major role in the mapping, coordination and logistic arrangements. With his presence in the field we 316 are very happy to thank P. Gerbeaux. For Vanuatu: The study was made possible by a grant 317 given to the French Ichtyological

318 Society in the framework of the 'Critical Ecosystem Partnership Fund (CEPF)' (Melanesia

319 hotspot). We acknowledge the Department of Environmental Protection and 320 Conservation for providing us the research permit. We thank the

321 TAFEA Province Secretary General, the Aneityum provincial area secretary, Mr Ruben 322 Niriam and the Tanna provincial area secretaries. We are particularly grateful to Chief Simon 
Nijina (Analcahat Chief), Chief Jack Nipveae (Secretary for the Nelvou Aneityum

324 Council of Chiefs), Chief Samson on Green Hill and Bob Kev (Green Hill school headmaster and his sister Marie Kev and to the local communities who allowed us to survey the rivers. This work was made possible thanks to the Service de Systématique Moléculaire of the MNHN and its staff for allowing us to produce the molecular data presented in this study.

Finally, we thank Tim Page and an anonymous reviewer for their helpful comments that helped us improve the manuscript.

\section{Litterature Cited}

Aznar-Cormano, L., J. Brisset, T. Y. Chan, L. Corbari, N. Puillandre, J. Utge, M. Zbinden, D. Zuccon and S. Samadi. 2015. An improved taxonomic sampling is a necessary but not sufficient condition for resolving inter-families relationships in Caridean decapods. Genetica 143:195-205.

Bracken, H. D., S. De Grave and D. L. Felder. 2009. Phylogeny of the Infraorder Caridea Based on Mitochondrial and Nuclear Genes (Crustacea: Decapoda). In J. W. Martin, K. A. Crandall, and D. L. Felder (Eds.), Decapod Crustacean Phylogenetics (pp. 281305).Chace, F. A. Jr. 1983. The Atya-like Shrimps of the Indo-Pacific Region (Decapoda: $\quad$ Atyidae). Sm. C. Zool. 384:1-54.

Choy, S., T. J. Page, and B. Mos. 2019. Taxonomic revision of the Australian species of Australatya Chace, 1983 (Crustacea, Decapoda, Atyidae), and the description of a new species. Zootaxa 4711:366-378.

Coleman, C. O. 2003. 'Digital inking': how to make perfect line drawings on computers. Org. Divers. Evol. 3 (Electronic Supplement 4):1-14. 
- 2006. Substituting time-consuming pencil drawings in arthropod taxonomy using stacks of digital photographs. Zootaxa 1360:61-68.

Cook, B. D., T. J. Page and J. M. Hughes. 2012. Phylogeography of related diadromous species in continental and island settings, and a comparison of their potential and realized dispersal patterns. J. Biogeo. 39:421-430.

Darriba, D., G. L. Taboada, R. Doallo, and D. Posada. 2012. jModelTest 2: more models, new heuristics and parallel computing. Nat. Methods, 9:772-772.

De Grave, S., C. P. Li, L. M. Tsang, K. H. Chu and T.-Y Chan. 2014. Unweaving hippolytoid systematics (Crustacea, Decapoda, Hippolytidae): resurrection of several families. Zool. Sci. 43:496-507.

Edgar, R.C. 2004. MUSCLE: multiple sequence alignment with high accuracy and high throughput. Nucleic Acids Res. 32(5), 1792-1797.

Felsenstein, J. 1985. Confidence limits on phylogenies: an approach using the bootstrap. Evolution 39:783-791.

Guindon, S. and O. Gascuel. 2003. A simple, fast, and accurate algorithm to estimate large phylogenies by maximum likelihood. Syst. Biol. 52:696-704.

Lorang, C., V. de Mazancourt, G. Marquet and P. Keith. 2020. Taxonomic study of the freshwater shrimps genus Atyoida Randall, 1840 (Crustacea: Decapoda: Atyidae) in Polynesia with a revalidation of A. tahitensis Stimpson, 1860. Zootaxa 4751:55-74.

Mary, N., A. Dutartre, P. Keith, G. Marquet, and P. Sasal. 2006. Biodiversité des eaux douces de Wallis et Futuna, Mission d'octobre 2004. Rapport final, Ministère de l'Outre-Mer. $84 p+$ annexes.

de Mazancourt V., G. Marquet, and P. Keith. 2017. The "Pinocchio-shrimp effect": First evidence of rostrum length variation with the Environment in Caridina H. Milne Edwards, 1837 (Crustacea: Decapoda: Atyidae). J. Crustacean Biol. 37:249-257. 
Miller, M. A., W. Pfeiffer, and T. Schwartz. 2010. Creating the CIPRES Science Gateway for inference of large phylogenetic trees. In: Proceedings of the Gateway Computing Environments Workshop (GCE), New Orleans, pp. 1-8.

Han, C. C., and W. Klotz. 2015. Australatya obscura sp. nov., a new filter-feeding shrimp (Decapoda, Atyidae) from Taiwan and the Philippines, Crustaceana 88:66-81.

Inui, N., T. Maruyama, and K. Okamoto. 2019. First record of Australatya obscura Han \& Klotz, 2015 (Decapoda, Atyidae) from the Ryukyu Islands, Japan. Biodivers. Data J. $7: 1-7$.

Keith, P., G. Marquet, P. Gerbeaux, E. Vigneux and C. Lord. 2013. Poissons et Crustacés d'eau douce de Polynésie: Taxonomie, écologie, biologie et gestion. Société Française d'Ichtyologie. 1-282.

Kumar, S., G. Stecher, M. Li, C. Knyaz, and K. Tamura. 2018. MEGA X: molecular evolutionary genetics analysis across computing platforms. Mol. Biol. Evol. 35:15471549.

Page, T. J., S. Choy, and J. M. Hughes. 2005. The taxonomic feedback loop: symbiosis of morphology and molecules. Biol. Letters 1:139-142.

Page, T. J., K. von Rintelen and J. M. Hughes. 2007. Phylogenetic and biogeographic relationships of subterranean and surface genera of Australian Atyidae (Crustacea: Decapoda : Caridea) inferred with mitochondrial DNA. Invert. Syst. 21:137-145.

Page, T. J., B. D. Cook, T. von Rintelen, K. von Rintelen and J. M. Hughes. 2008. Evolutionary relationships of atyid shrimps imply both ancient Caribbean radiations and common marine dispersals. J. N. Am. Benthol. Soc. 27:68-83.

Page, T. J., and J. M. Hughes. 2011. Neither molecular nor morphological data have all the answers; with an example from Macrobrachium (Decapoda: Palaemonidae) from Australia. Zootaxa 2874:65-68. 
Porter, M. L., M. Perez-Losada and K. A. Crandall. 2005. Model-based multi-locus estimation of decapod phylogeny and divergence times. Mol. Phyl. Evol. 37:355-369.

Puillandre, N., A. Lambert, S. Brouillet, and G. Achaz. 2011. ABGD, Automatic Barcode Gap Discovery for primary species delimitation. Mol. Ecol. 21:1864-1877.

von Rintelen, K., and Y. Cai. 2009. Radiation of endemic species flocks in ancient lakes: systematic revision of the freshwater shrimp Caridina H. Milne Edwards, 1837 (Crustacea: Decapoda: Atyidae) from the ancient lakes of Sulawesi, Indonesia, with the description of eight new species. Raffles B. Zool. 57:343-452.

Smith, M. J., and W. D. Williams. 1982. Taxonomic revision of Australian species of Atyoida Randall (Crustacea: Decapoda: Atyidae), the genera Atyoida and Atya Leach. Mar. Freshwater Res. $33: 343-361$.

Table 1: Sequences data.

Tables and Figure captions

Figure 1: Phylogenetic tree of Australatya keithi sp. nov. and other Indo-Pacific Atya-like species built using Bayesian Inference. Values above branches indicate posterior probabilities, those below are bootstrap values. Scale represents genetic distance.

Figure 2: Australatya keithi sp. nov.. a. first pereiopod; b. second pereiopod; c. third pereiopod; d. fifth pereiopod; e. dactylus of third pereiopod; f. dactylus of fifth pereiopod; g. developed eggs; h. uropodal diaeresis; i. pre-anal carina; j. telson; k. male first pleopod; 1. 
422 male second pleopod; m. cephalothorax. MNHN-IU-Na-15761: a, b, c, d, e, f, h, i, j, m;

423 MNHN-IU-2018-3301: g; MNHN-IU-2018-3306: k, 1.

424

425 Figure 3: A: Live coloration of an ovigerous female of Australatya keithi sp. nov. caught on 426 Santo Island (Vanuatu), credit P. Keith. B: Vainifao River on Futuna Island (Wallis and 427 Futuna Territory, France), habitat of Australatya keithi sp. nov., credit A. Dutartre.

428

429 Figure 4: Current known geographical distribution of the four species of Australatya. Red 430 dotsdots indicate sampling sites from the present study. 